\title{
Isolation, fractionation and anticoagulant activity of a sulfated galactan extracted from the green algae Penicillus capitatus
}

\author{
Thamyris Almeida Moreira ${ }^{1}$ (i) Bianca Barros da Costa $^{1}$ (D) Regina Célia Alves Celestino ${ }^{1}$ (i) \\ Caroline Nogueira Faria ${ }^{1}$ Jéssica Lopes D’Dego Gianelli ${ }^{1}$ (i) Gustavo Ramalho Cardoso dos Santos ${ }^{2}$ \\ Bianca Fernandes Glauser ${ }^{2}$ Angélica Ribeiro Soares ${ }^{3}$ Paulo Antônio de Souza Mourão ${ }^{2}$ \\ Carlos Rangel Rodrigues ${ }^{4}$ Leonardo Paes Cinelli $^{1^{*}}$
}

${ }^{1}$ Grupo de Glicofármacos, Universidade Federal do Rio de Janeiro (UFRJ), 27930-560, Macaé, RJ, Brasil. E-mail: cinelli@pharma.ufrj.br. ${ }^{2}$ Laboratório de Tecido Conjuntivo, Universidade Federal do Rio de Janeiro (UFRJ), Rio de Janeiro, RJ, Brasil.

${ }^{3}$ Núcleo em Ecologia e Desenvolvimento Sócioambiental de Macaé (NUPEM), Universidade Federal do Rio de Janeiro (UFRJ), Macaé, RJ, Brasil. ${ }^{4}$ Laboratório ModMolQSAR, Universidade Federal do Rio de Janeiro (UFRJ), Rio de Janeiro, RJ, Brasil.

ABSTRACT: Marine algae are natural sources of macromolecules known as sulfated polysaccharides. This class of compounds has attracted the interest of Pharmaceutical Sciences due to its pharmacological anticoagulant, antiplatelet and antithrombotic properties. Therefore, this study evaluated the anticoagulant potential of sulfated polysaccharides extracted from the algae Penicillus capitatus. The extracted sulfated polysaccharides were purified, partially characterized and their anticoagulant activity was evaluated. The extraction process followed by ethanol precipitation resulted in five fractions. Among the analyzed fractions, F44 contained highest concentration of sulfated polysaccharides. After the purified fraction F23, F44 displayed in vitro anticoagulant activity in a time testing for activated partial thromboplastin time and prothrombin time. The preferential mechanism effect was based on interactions between thrombin and factor Xa. Additional studies on structure pharmacological are required to test the viability of the use of sulfated polysaccharides as therapeutic agents.

Key words: sulfated polysaccharide, marine algae, anticoagulant activity, Penicillus capitatus.

Isolamento, fracionamento e atividade anticoagulante da galactana sulfatada extraída da alga verde Penicillus capitatus

\begin{abstract}
RESUMO: As algas marinhas são fontes naturais de macromoléculas conhecidas como polissacarídeos sulfatados. Esta classe de compostos atraiu o interesse das Ciências Farmacêuticas devido às suas propriedades farmacológicas como anticoagulante, antiplaquetária e antitrombótica. Portanto, este estudo tem como objetivo avaliar o potencial anticoagulante de polissacarídeos sulfatados extraídos de algas de Penicillus capitatus. Os polissacarideos sulfatados extraidos foram purificados, parcialmente caracterizados e sua atividade anticoagulante foi avaliada. O processo de extração seguido pela precipitação com etanol resultou em cinco frações. Entre as frações analisadas, F44 foi a maior concentração de polissacarídeos sulfatados. Após a purificação, as frações F23 e F44 mostraram atividade anticoagulante in vitro em um teste de tempo de tromboplastina parcialmente ativada e tempo de protrombina. Seu mecanismo preferencial é baseado nas interações entre trombina e fator Xa. Estudos adicionais sobre a estrutura farmacológica são necessários para testar a viabilidade do uso como agente terapêutico. Palavras-chave: polissacarídeo sulfatado, algas marinhas, atividade anticoagulante, Penicillus capitatus.
\end{abstract}

\section{INTRODUCTION}

Thousands of new substances have been identified in marine organisms in the last three decades, revealing their potential as a prototype source displaying biological activity (TEIXEIRA, 2009). The Brazilian coast, about $8,000 \mathrm{~km}$ long, comprises one of the higher recorded marine biodiversity, with a significant molecular diversity for the study of marine bioprospecting (BERLINCK et al., 2004). Therefore, it is currently believed that the sea offers the largest natural molecule reserve for pharmacological assessments (ROCHA et al., 2005). One of the most noteworthy marine organisms as a source of active compounds are marine algae, or seaweed, photosynthetic beings classified into three classes according to their color (BONEY, 1966).

Among several active compounds, sulfated polysaccharides (SP) are noteworthy, displaying structural heterogeneity due to the 
possibilities of constituent sugar, in the presence of a sulfate group, which may vary in amount as well as position. The main families constituting this class are sulphated galactans, sulfated fucans and heteropolysaccharides (HAROUN-BOUHEDJA et al., 2000). These molecules are bioactive and display significant potential in medical, pharmaceuticals and biotechnology applications.

Some SP synthesized by marine algae include sulfated galactans produced by red algae (Rhodophyta) (PEREIRA et al., 2005), sulfated fucans produced by brown algae (Phaeophyta) (CHEVOLOT et al., 1999), and sulfated glucans, sulfated galactans and sulfated arabinogalactan produced by green algae (Chlorophyta)(UEHARA et al., 1992; MATSUBARA et al., 2000). A lack of reports concerning SP structures biosynthesized by green algae (Chlorophyta); however, is noted, that most display a predominance of galactans (BILAN, VINOGRADOVA, SHASHKOV, \& USOV, 2007; CHATTOPADHYAY et al., 2007; CIANCIA et al., 2012).

Among SP biological properties, anticoagulant activity is one of the most studied (FARIAS et al., 2000; MATSUBARA et al., 2001; MOURÃO, 2004; PEREIRA et al ., 2005; ATHUKORALA et al, 2006; ZHANG et al, 2008). The SP of several seaweed species have been studied and tested and a sulfated galactan displaying more powerful anticoagulant activity than unfractionated heparin has been identified (FARIAS et al., 2008; FARIAS, et al., 2001).

Heparin is the most widely applied antithrombotic agent in clinical practice as a systemic therapy in cardiovascular or thromboembolic diseases. It is the greatest example of an SP with anticoagulant activity, directly related to its structure, such as a glycosidic bond, sulfation pattern, monosaccharide composition and molecular weight (BLOSSOM et al., 2008). However, several side effects are noted for heparin, such as the development of thrombocytopenia, arterialembolis (WARKENTIN \& KELTON, 2001) and bleeding complications (KELTON \& HIRSH, 1980), among others. ARATA et al. (2015) conducted studies with the macroalgae Penicillus capitatus; although, applying different extractive procedures and; consequently, obtaining dicrepant results from those described in the present study, which will be discussed ahead.

In this study, SP synthesized by $P$. capitatus collected in Brazil, were examined. The SP were extracted and purified using chromatographic techniques, and partially characterized by Fourier transform infrared (FT-IR) spectroscopy analysis and gas chromatography-mass spectrometry (GC-MS). In vitro anticoagulant SP activities were evaluated and its mechanism of action was partially elucidated by enzymatic assays.

\section{MATERIALS AND METHODS}

\section{Marine algae collection}

The marine algae Penicillus capitatus was collected at Cumuxuratiba beach (17 $6^{\circ}$ '57.841" S $39^{\circ} 10^{\prime} 18.779$ ' W), Prado, Bahia, Brazil, washed in seawater to eliminate associated organisms, separated from epiphytes and other species, further washed with distilled water, air-dried, powdered and stored at $-20{ }^{\circ} \mathrm{C}$. The algae was collected by A. R. Soares and identified by L. M. S. Gestinari and Y. YoneshigueValentin. Voucher specimens were deposited at RFA (THIERS, 2008).

\section{Proteolitic SP extraction}

The collected marine algae were immersed in acetone P.A., and maintained for $24 \mathrm{~h}$ at $4{ }^{\circ} \mathrm{C}$. The pellet was dried at $60{ }^{\circ} \mathrm{C}$ and each $10 \mathrm{~g}$ was suspended in extraction buffer $(0.1 \mathrm{M} \mathrm{NaOAc}, 5.0 \mathrm{mM}$ EDTA and $5.0 \mathrm{mM}$ cysteine, $1.0 \mathrm{~g}$ of papain in $\mathrm{pH} 6.0)$ and incubated at $60{ }^{\circ} \mathrm{C}$ for $12 \mathrm{~h}$ under stirring (SL-222, SOLAB, Piracicaba (SP) Brazil) at $200 \mathrm{rpm}$. The incubation mixture was then centrifuged (LS-3 plus, CELM, São Caetano do Sul, Brazil) for $2500 \mathrm{x} g$ for $20 \mathrm{~min}$ at room temperature) and the supernatant was separated. The residue was resuspended in the same extraction buffer until the absence of SP in supernatant was checked by metachromasia properties with DMB at $\mathrm{A}_{525}$ (FARIAS et al., 2000). Supernatants positive for metachromasia properties were combined and termed the crude extracts. The SP were precipitated in the presence of increasing ethanol concentrations of $9 \%, 23 \%, 45 \%, 60 \%$ and $75 \%$. Each precipitate was exhaustively dialyzed for 24 hours, freeze-dried and stored at $-20{ }^{\circ} \mathrm{C}$ (Figure 1). The dry weight of the crude extracts was obtained following these procedures, where the yield was calculated using the following equation: Polysaccharide Yield $(\%)=[($ weight of the dry seaweed (g)/weight of the dry crude polysaccharide (g)] x 100 (BRANDÃO et al., 2020).

\section{Agarose gel electrophoresis}

SP were analyzed by agarose gel electrophoresis as described previously by DIETRICH \& DIETRICH (1976). Samples ( 15 $\mathrm{mg}$ ) were applied to a $0.5 \%$ agarose gel and run for $1 \mathrm{~h}$ at $110 \mathrm{~V}$ in $0.05 \mathrm{M} \mathrm{1,3-diaminopropane-acetate}$ ( $\mathrm{pH}$ 9.0). CS and heparin were used as standards. The 


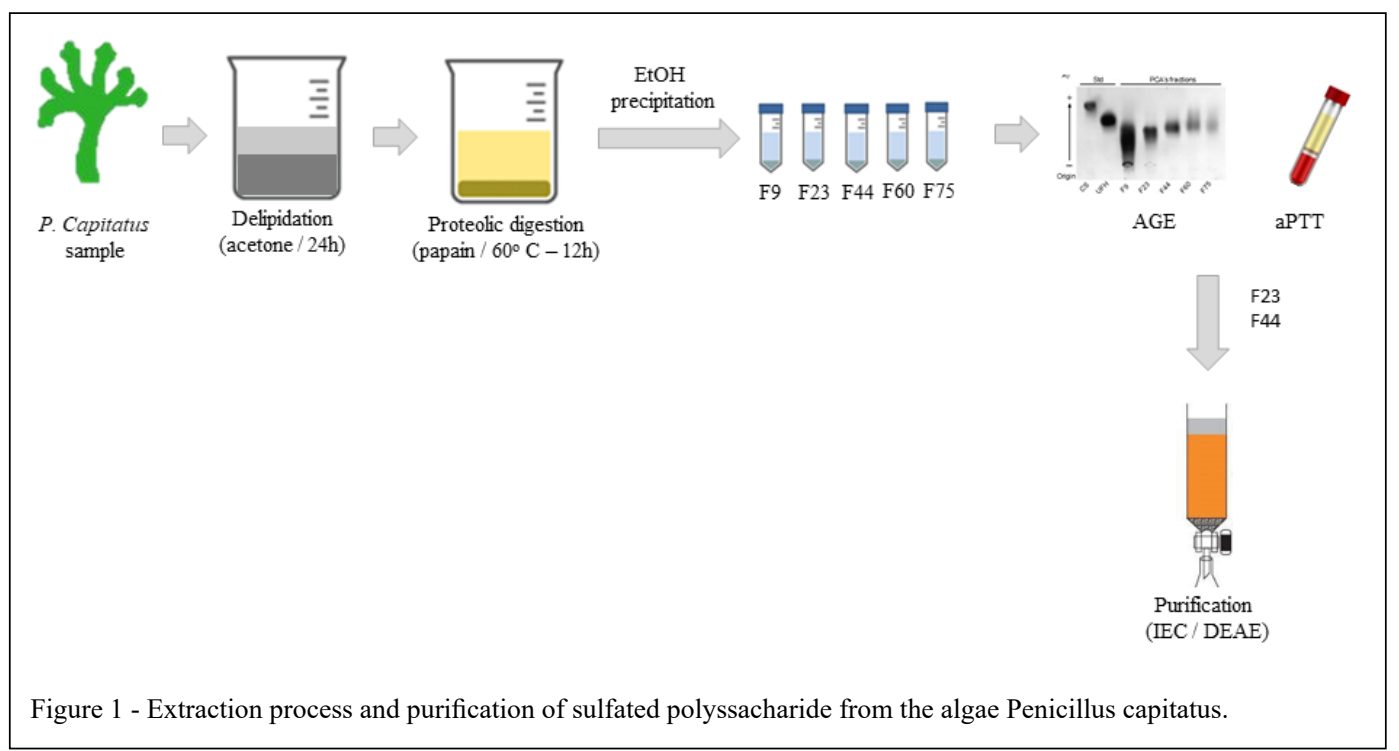

SP in the gel were fixed with $0.1 \% N$-cetyl- $N, N, N$ trimethylammonium bromide solution at room temperature, and, after $12 \mathrm{~h}$, the gel was dried and stained for $15 \mathrm{~min}$ at room temperature with $0.1 \%$ toluidine blue in 0.1:5:5 HOAc-EtOH-water ( $\mathrm{v} / \mathrm{v})$.

\section{Clotting assay}

Anticoagulant action measured by activated partial thromboplastin time (aPTT) and prothrombin time (PT) clotting assays were recorded using a coagulometer (Amelung KC4A), following the protocols provided by commercial kits from Instrumentation Laboratory (Bedford, MA, USA) and Inlab (São Paulo, SP, Brazil). Briefly, blood collected from healthy adult, both male and female, was collected by venous punction and mixed with $3.2 \%$ sodium citrate at a 9:1 ratio, kindly donated by the Clementino Fraga Filho University Hospital, belonging to the Federal University of Rio de Janeiro or by the Municipal Hemotherapy Service of Macaé. Citrated plasma was obtained by blood centrifugation $(1000 \times \mathrm{g}$ for $10 \mathrm{~min}$ at room temperature). Clotting assays were carried out using positive controls (unfractionatred heparin $200 \mathrm{IU} / \mathrm{mg}$ ) and SP obtained from $P$. capitatus, at different concentrations. All assays were performed in duplicate and repeated at least three times on different days $(\mathrm{n}=6)$ (ANDERSON et al., 1976).

\section{Purification of seaweed SP}

The SP precipitated in the presence of ethanol $(10 \mathrm{mg})$ was dissolved in $5 \mathrm{~mL}$ of $20 \mathrm{mM}$ TRIS-
$\mathrm{HCl}, 50 \mathrm{mM}$ EDTA (pH 7.4), applied to a DEAEcellulose column $(10 \mathrm{~cm} \times 2.0 \mathrm{~cm})$, equilibrated with the same solution and washed with $50 \mathrm{~mL}$ of the same buffer. A linear gradient of $4.0 \mathrm{M} \mathrm{NaCl}$ in the same solution was used as eluent, at a flow rate of 0.5 $\mathrm{mL} / \mathrm{min}$. One milliliter fractions were collected and assayed for SP using the metachromatic assay with DMB, conductivity and hexose dosage. The DEAEcellulose peak was applied to a High Q - HPLC set at the same equilibration, elution, collection and fraction checking conditions (CINELLI et al., 2009).

Effect of SP on thrombin or factor Xa inactivation mediated by antithrombin

Increasing SP concentrations in TS/PEG buffer $(0.02 \mathrm{M}$ Tris/ $\mathrm{HCl}, 0.15 \mathrm{M} \mathrm{NaCl}$ and $1.0 \mathrm{mg}$ $\mathrm{mL}^{-1}$ polyethylene glycol 8000, $\mathrm{pH} 7.4$ ), containing either $10 \mathrm{mM} \mathrm{CaCl}_{2}$ or $20 \mathrm{mM}$ EDTA, were incubated for $5 \mathrm{~min}$ at $37^{\circ} \mathrm{C}$, with $5 \mathrm{nM}$ antithrombin and 0.5 $\mathrm{nM}$ factor Xa or thrombin. Residual factor $\mathrm{Xa}$ or thrombin activities were determined by the addition of $100 \mu \mathrm{M}$ of the chromogenic substrate S-2765 or $\mathrm{S}-2238$ (HemosIL ${ }^{\mathrm{TM}}$ ), respectively, in a final volume of $100 \mu \mathrm{L}$. Substrate hydrolysis was detected as described above.

Fourier transform infrared (FT-IR) spectroscopy analysis

The spectroscopic measurements were performed using approximately $1 \mathrm{mg}$ of each samples mixed with $100 \mathrm{mg}$ of dried $\mathrm{KBr}$ crystal. FT-IR spectra between 400 and $4000 \mathrm{~cm}^{-1}$ were recorded 
using a FT-IR spectrometer. Background noise was corrected using pure $\mathrm{KBr}$ data (DENG et al., 2020).

\section{Chemical analyses and monosaccharide composition} Total sugars were estimated by the phenol$\mathrm{H}_{2} \mathrm{SO}_{4}$ reaction using D-glucose as standard, as described by DUBOIS et al (1956). Sulfate content was determined according to the barium gelatin method (DODGSON \& PRICE, 1962), using a standard sodium sulfate curve $(1 \mu \mathrm{g} / \mu \mathrm{L})$. Protein content was determined by the modified Bradford method (1976) using bovine serum albumin as standard. The purified soluble fraction and monosaccharide standard were hydrolyzed in $6 \mathrm{M}$ trifluoroacetic acid for $5 \mathrm{~h}$ at $100{ }^{\circ} \mathrm{C}$, component sugars were reduced with borohydride and the resulting alditols were acetylated with 1:1 $\mathrm{Ac}_{2} \mathrm{O}$-pyridine. Alditol acetate sugars were dissolved in $\mathrm{CHCl}_{3}$ and were estimated by gas chromatography-mass spectrometry (GCMS) (KIRCHER, 1972). The retention time of the monosaccharide standards were compared with monosaccharides obtained from PCA F44 P1.

\section{RESULTS AND DISCUSSION}

Extraction, pre-purification and preliminary analysis of SP extracted from $P$. capitatus

The SPs were extracted with proteolytic treatment until non-detection in the supernatants. After eight successive papain proteolitic extractions, each extract was individually analyzed by agarose gel electrophoresis, and all exhibited the same polydispersity pattern, with one band migrating slower than heparin (data not shown). Because of this, the eight extracts were pooled (termed the crude extract), precipitated with increasing ethanol concentrations $(9 \%, 23 \%, 44 \%, 60 \%$ and $75 \%)$ and five different fractions were obtained, namely F9, F23, F44, F60 and F75.

The dry weight obtained for each fraction was compared to the initial algae weight and the percent yield of each fraction was then obtained (Table 1). The F75 fraction presented the highest yield, of $5.9 \%$ of the total polysaccharide mass extracted from seaweed, while F9 presented the lowest yield $(1.1 \%)$. The other fractions showed percentage yields of $3.4,3$ and 1.8 , respectively. ARATA et al. (2015) obtained lower yields, ranging from $0.05 \%$ to $1.3 \%$, due to the fact that they did not use enzymes in the SP extraction process, but, instead, water at room temperature and hot water and methanol. When using proteolytic enzymes such as papain, SP extraction from the rodoficea seaweed Botryocladia occidentalis (FARIAS et al., 2000) and the chloroficea Caulerpa sertularioides (BEZERRANETO et al., 2008) were of $4 \%$ and $3.3 \%$, respectively. Both authors used a single precipitation with three volumes of ethanol relative to the crude extract for SP extraction. Therefore, the $P$. capitatus alga yield was 3-5 fold higher than Botryocladia occidentalis and Caulerpa sertularioides, respectively. This higher percentage is probably due to negligible proteolysis protein digestion in all fractions. The low protein percentage detected reflects the efficiency of the enzymatic digestion method during SP extraction. Conversely, uronic acids and hexoses were present in all five fractions. Concerning sulfate, different values were observed in the obtained fractions, where the

Table 1 - Chemical analysis of SP fractions from $P$. capitatus seaweed.

\begin{tabular}{lcccccc}
\hline PCA fraction & Yield a (\%) & Carbohydrates b (\%) & Protein c (\%) & Uronic acid d (\%) & SP (\%) e & Monossacharide f \\
\hline F9 & 1.1 & 53.8 & 0.34 & 18.4 & 0.15 & - \\
F23 & 3.4 & 60.3 & 0.04 & 9.2 & 1.51 & - \\
F44 & 1.8 & 25.1 & 0.1 & 15.6 & 2.22 & 1.99 \\
F60 & 3.0 & 57.4 & N.D. & 24.9 & 1.21 & - \\
F75 & 5.9 & 64 & 0.13 & 24.2 & Gal \\
\hline
\end{tabular}

a Initial weight of the algae was of $22.5 \mathrm{~g}$.

b phenol $/ \mathrm{H}_{2} \mathrm{SO}_{4}$.

c protein dosage.

d carbazol dosage.

e barium gelatin method.

f retention time on a gas chromatography/mass spectrometry.

not detected (ND). 
F9 fraction contained the lowest amount of sulfate, $0.15 \%$, and the F44 fraction, the highest, $2.22 \%$ (Table 1). Sulfate contents were different from the values reported by ARATA et al., between $2.4 \%$ and $10.4 \%$, due to different extraction methods.

After the chemical analyses, each fraction was submitted to the electrophoresis runs and coagulation assays of activated partial thromboplastin time (aPTT). The electrophoresis revealed that F75 poorly dyed with toluidine blue, suggesting low sulfate content, while the F9 showed a highly polydisperse band pattern quite different from the other fractions, which strongly indicates a fraction containing heterogeneous SP. Fractions F23, F44 and F60 displayed slower migration compared to heparin (Figure 2A).

The five fractions were submitted to anticoagulant in vitro aPTT assay, where F60 and F75 did not display any anticoagulant activity at any evaluated concentration. This confirms the direct relationship between anticoagulant activity and staining with toluidine blue, as a lower degree of sulfation leads to lesser interaction and, thus, toluidine blue metachromatic band intensity (Figure 1A) (CUMASHI et al., 2007). Fraction F9 displayed intermediate aPTT activity, while F23 and F44 displayed a maximal anticoagulant effect, with prolonged time at $6 \mathrm{IU} / \mathrm{ml}$ and $20 \mathrm{IU} / \mathrm{ml}$, respectively, using as a standard heparin at $0.1 \mathrm{IU} / \mathrm{ml}$ (Figure 2B). $S P$ purification from $P$. capitatus
The two fractions (F23 and F44) displaying anticoagulant activity in the aPTT assay were submitted to DEAE-cellulose separation to separate SP from other possible components. One methacromatic peak eluted at $\sim 1.75 \mathrm{M} \mathrm{NaCl}$ in F23 (Figure 3A) and $\sim 1.4$ in F44 (Figure 3C), with no altered electrophoretic mobility prior to the purification step (Figure 3B and D). Additionally, PCA F23 P1 and PCA F44 P1 were chromatographed on a High Q-HPLC system, and one peak eluted at $1.9 \mathrm{M}$ and $\sim 1.2 \mathrm{NaCl}$, respectively (data not shown). Usually, SP extracted by seaweeds eluted at $\mathrm{NaCl}$ molarities similar to the molarities observed in weak and strong anion-exchange chromatography, DEAEcellulose and High Q, respectively, used in these experiments (PEREIRA et al., 2005; PEREIRA et al., 1999). The fact that their electrophoresis mobility was not altered after the purification step and the presence of only one methacromatic peak observed after DEAE-cellulose and High Q separations indicated the high purity of this fraction.

\section{Clotting times of SP extracted from P.capitatus}

The next step was to assay the in vitro anticoagulant activity by the aPTT assay of F23 P1 and F44 P1 (Figure 4). Both purified fractions prolonged aPTT to a maximum, with F44 P1 reaching the maximum at $2 \mathrm{IU} / \mathrm{mL}$ (Figure $4 \mathrm{~B}$ ), and fraction $\mathrm{F} 23 \mathrm{P} 1$, at $6 \mathrm{IU} / \mathrm{mL}$ (Figure $4 \mathrm{~A}$ ), compared to the
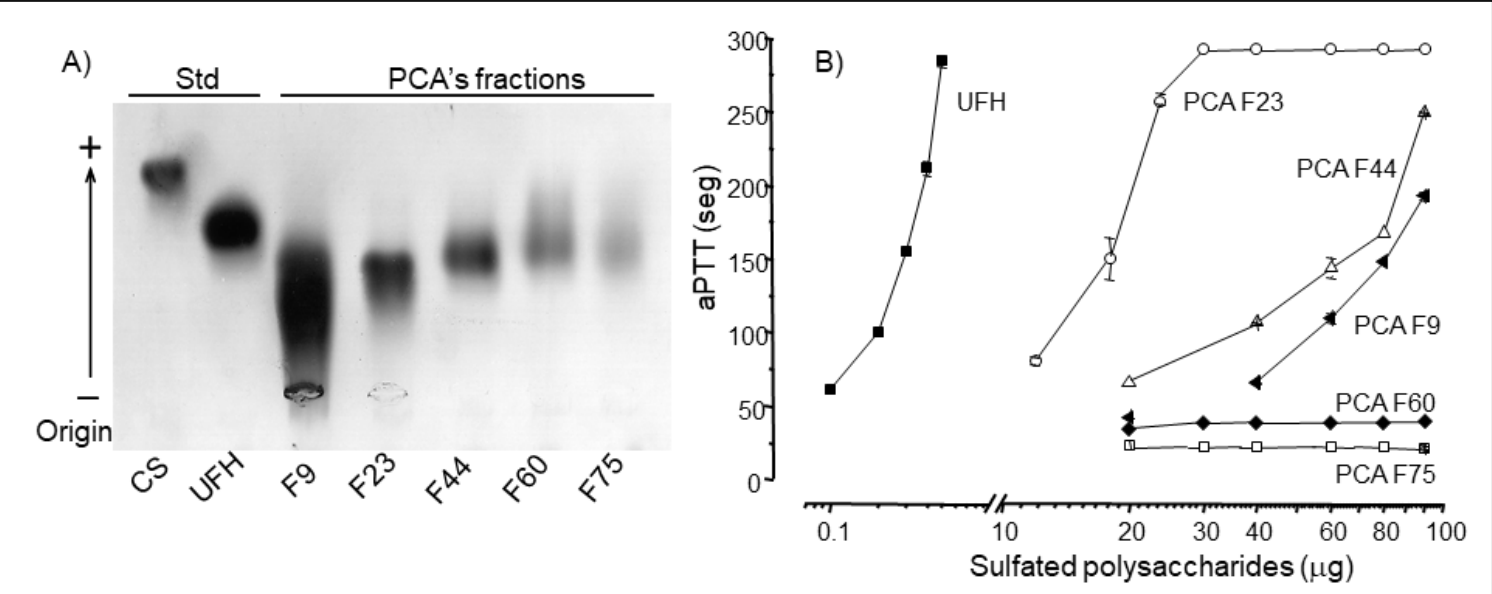

Figure 2 - SP obtained from sequential increasing ethanol concentrations from P.capitatus were submitted to electrophoresis and the aPTT assay. In (A) precipitations were applied on a $0.5 \%$ agarose gel and stained with $0.1 \%$ toluidine blue in acetic acid:ethanol:water $(0.1: 1: 5, \mathrm{v} / \mathrm{v})$. (B) The in vitro aPTT clotting assay was performed using normal human plasma at different SP concentrations; PCA F9 ( ), PCA F23 (o), PCA F44 ( $\Delta$ ), PCA F60 ( ), PCA F75 ( $\square$ ) and unfractionated heparin standard (UFH) (匹). 


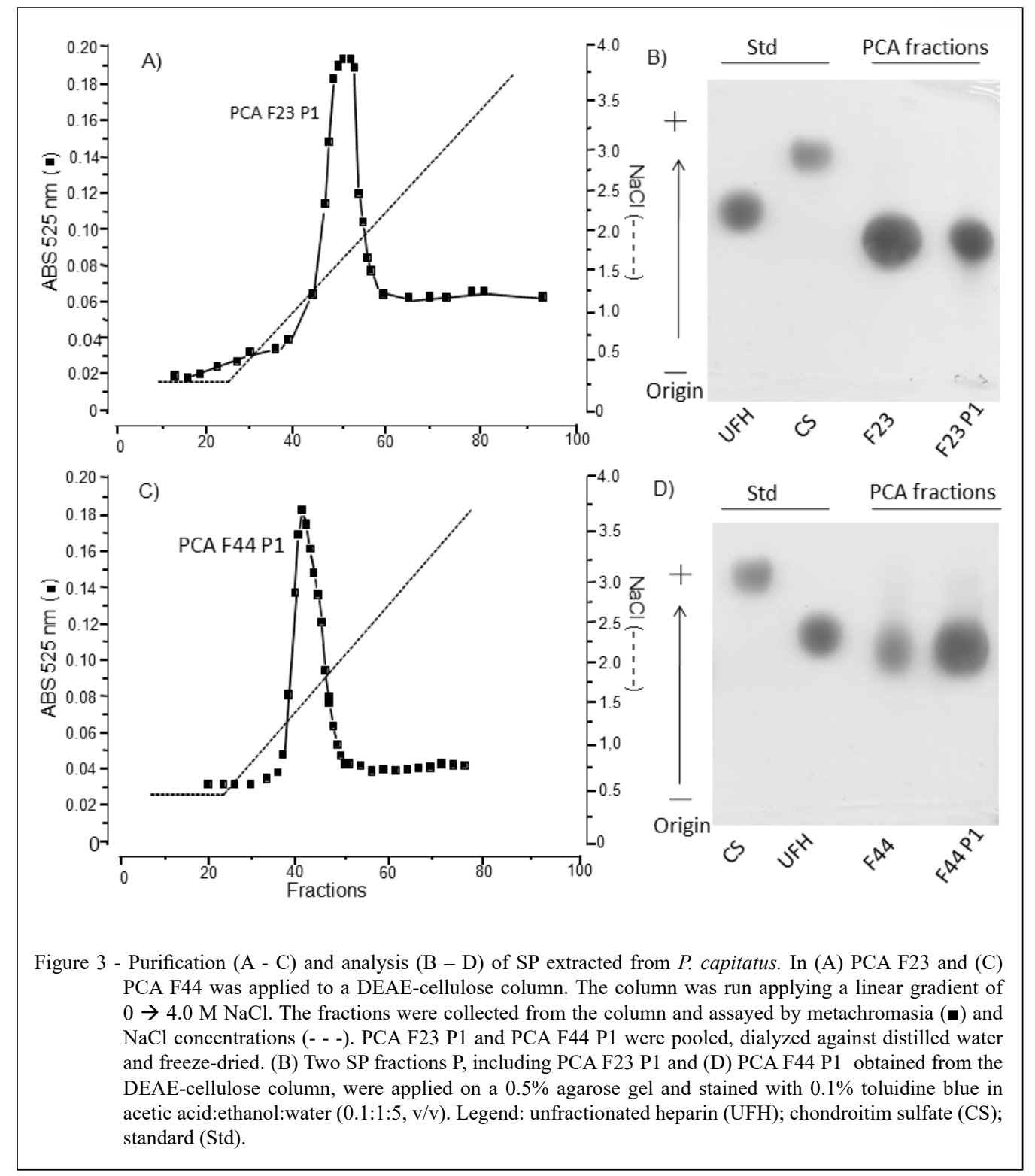

heparin standard at $0.1 \mathrm{IU} / \mathrm{mL}$. When compared to heparin, PCA F23 P1 and PCA F44 P1 activities were 60- and 20-fold lower, respectively. Coagulation inhibition was also observed in the prothrombin time test (Figure 4C and 4D) at $16 \mathrm{IU} / \mathrm{mL}$ for both fractions compared to a heparin standard at $3 \mathrm{IU} / \mathrm{mL}$.

These in vitro anticoagulant activity assays indicates that SP (PCA F23 P1 and PCA F44 P1) extracted from $P$. capitatus inhibited proteins involved in both intrinsic and extrinsic pathways. This contrasts with the results reported by ARATA et al. (2015), as their fractions did not demonstrate activity via PT, corroborating the structural differences between the extracted SP, while according to some researchers, SP extracted from algae (Codium isthmocladum, Vochysia tucanorum) do not show significant activity in both coagulation system of pathways (LEITE et al., 1998).

The action of SP coagulation occurs not merely as a function of charge density, but also due to monosaccharide composition, sulfate groups position and, especially, the occurrence of sulfated units (MOURÃO, 2004). Therefore, chemical characteristics are also prerequisites for correlating the biological functions of these compounds with their structures (MOURÃO, 2004; PEREIRA, 1999; FONSECA et al., 2008; ZHANG et al., 2008). 


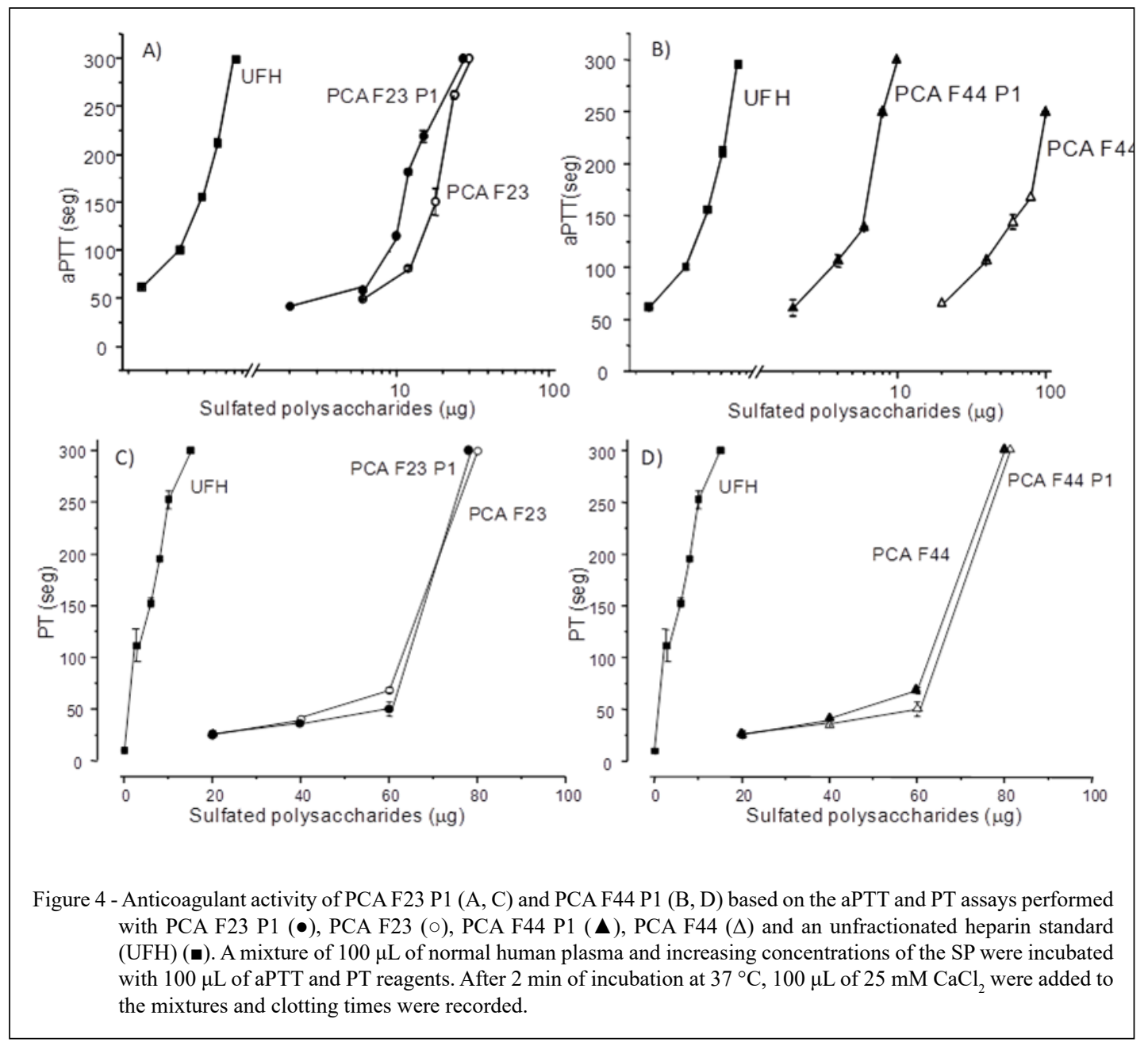

Usually, sulfated galactans display better activity than sulfated fucans. Currently, it is clear that a robust comparison between several molecules can only be made with the integral elucidation of galactan (glycoside linkage, sulfation pattern), since these characteristics are essential for a thorough assessment of the requirements for biological activity maintenance (POMIN \& MOURÃO, 2014). These results indicate that structural analyses of SP from P.capitatus and their tests using specific biological assays are useful tools to investigate molecular anticoagulant activity mechanisms in mammals.

Effect of SP on the inactivation of thrombin or factor Xa mediated by antithrombin

In order to explore the anticoagulant action mechanisms of fractions F44 and F23, blood coagulation system factors teste were carried out. F23
P1 and F44 P1 exhibited significant activity in the factor $\mathrm{Xa}$ test . The minimum concentration required to inhibit half of the activity (IC50) was of 0.0005 $\mathrm{IU} / \mathrm{mL}$ for PCA F23 P1 and of $0.005 \mathrm{IU} / \mathrm{mL}$ for PCA F44 P1 compared to a heparin standard at 0.00005 UI $/ \mathrm{mL}$. Therefore, PCA F23 P1 exhibited only a 10-fold lower concentration compared to heparin (Figure 5A). Both fractions also displayed activity against thrombin, with the IC50 for PCA F23 P1 determined as $0.01 \mathrm{IU} / \mathrm{ml}$ and for PCA F44 P1, of $0.03 \mathrm{IU} / \mathrm{ml}$, compared to a heparin standard at 0.0001 $\mathrm{IU} / \mathrm{ml}$ (Figure 5B). Consequently, the mechanism of action for both fractions is preferably through the factor Xa pathway (Figure 5). These results are in contrast with those reported by ARATA et al. (2015), who suggest a mechanism of action mediated by thrombin, which demonstrates the structural difference of the extracted SP. 


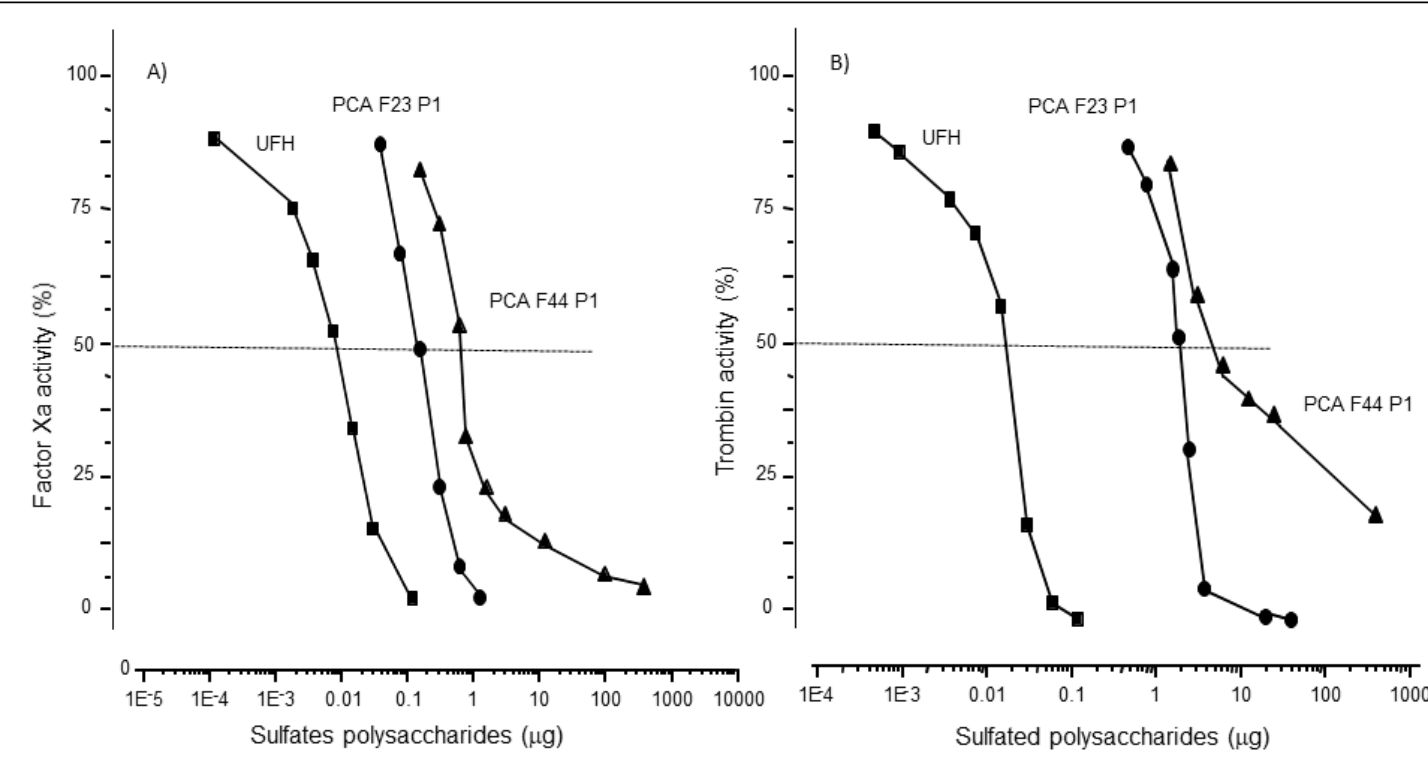

Figure 5 - Effect of SP on the inactivation of thrombin or factor Xa mediated by antithrombin. Thrombin (0.5 nM) or factor Xa $(0.5 \mathrm{nM})$ inactivation by antithrombin $(5 \mathrm{nM})$ was monitored at increasing heparin concentrations (匹), PCA F23 P1 $(\bullet)$ or PCA F44 P1 ( $\boldsymbol{\Delta})$ in TS/PEG buffer.

Many different anticoagulant mechanisms have been reported for SP isolated from algae (POMIN \& MOURÃO, 2014). FARIAS et al. (2000) detected strong anticoagulant activity of sulfated $D$-galactan extracted from the red seaweed B. occidentalis, where activity mediated thrombin inhibition by antithrombin and heparin cofactor II in the presence of two sulfate esters in a single galactose residue. MATSUBARA et al. (2001) reported that the isolated polysaccharide of the green seaweed Codium cylindricum has a direct inhibitory mechanism on thrombin, independent of antithrombin and heparin cofactor II. Increasing evidence; however, suggests that distinct sulfation patterns and structural motifs of the saccharide chains are involved in performing specific interactions with proteins belonging to the coagulation system (PEREIRA et al., 2002; PEREIRA et al., 2002).

Fourier transform infrared (FT-IR) spectroscopy analysis

A spectroscopy test was performed in the infrared region to analyze the primary structural characteristics of the SP present in the PCA F23 P1 and PCA F44 P1 fractions (Figure 6). The spectra indicated characteristic carbohydrate bands, such as that located at $1250 \mathrm{~cm}^{-1}$ (band 5), confirming a bond between monomers due to the typical stretching of the C-O-C bond. The most prominent band was observed between 3500-3300 $\mathrm{cm}^{-1}$ (band 1), corresponding to the stretching of the $\mathrm{O}-\mathrm{H}$ bond, characteristic of monosaccharides. The presence of characteristic sulphate group signs is also noted, such as the stretching of the $\mathrm{S}=\mathrm{O}$ bond between $1050-950 \mathrm{~cm}^{-1}$ (band 6) and the stretching of the C-O bond by $600 \mathrm{~cm}^{-1}$ (band 7). The PCA F44 P1 fraction was more intense in band 6 , confirming the higher sulfate content observed in chemical dosages. (SILVERSTEIN et al., 2006; WU et al., 2013). Bands referring to the stretching of the $\mathrm{C}-\mathrm{H}$ bond at around $2900 \mathrm{~cm}^{-1}$ (band 2) and $\mathrm{COO}^{-}$or $\mathrm{OH}$ at around $1650 \mathrm{~cm}^{-1}$ (band 3), associated with the carboxylic acid group of the uronic acid, were also verified, also confirming the data obtained in the chemical uronic acid analysis (Table 1) (SILVERSTEIN et al., 2006, WU et al., 2013). The band present at $1400 \mathrm{~cm}^{-1}$ (band 4) would correspond to the carboxyl group belonging to pyruvic acid (ESTEVEZ et al., 2009), thus confirming the data obtained by ARATA et al. (2015), who described the composition of the SP present in the $P$. capitatus as being a pyruvated sulfated galactan. 


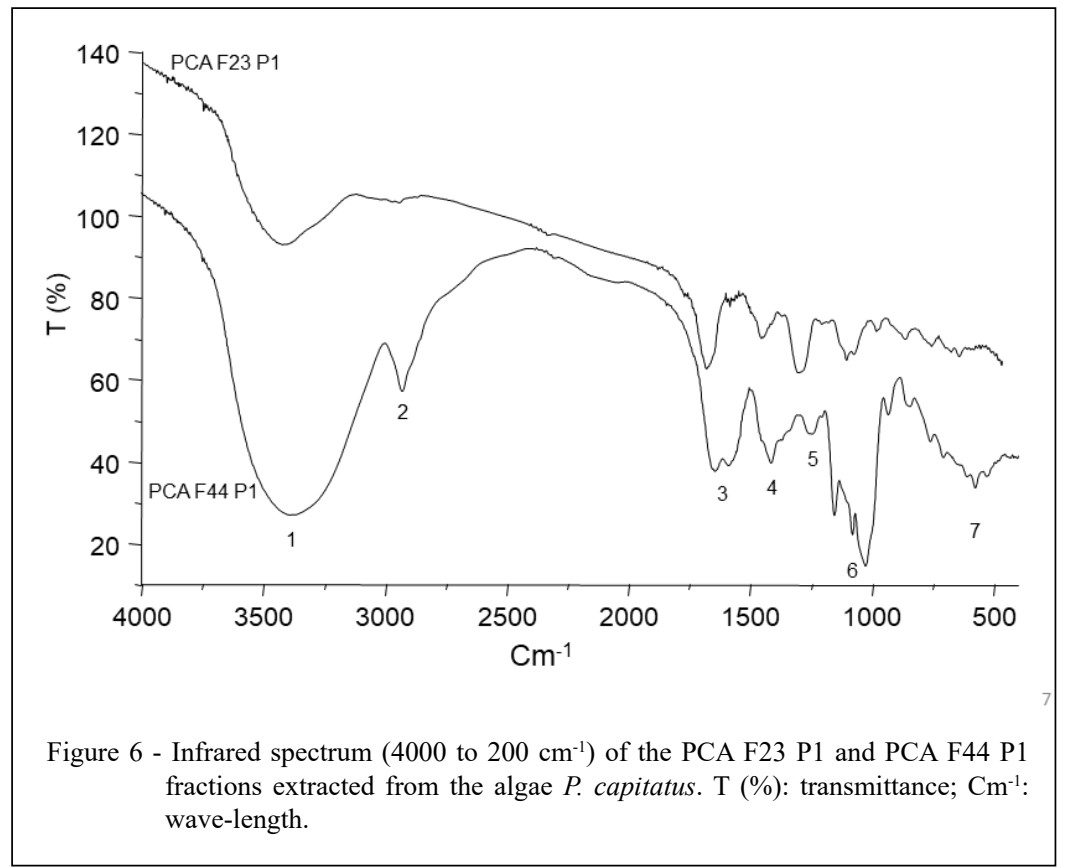

PCA F44 P1 monosaccharide analysis by gas chromatography

Although, the PCA F23 P1 and PCA F44

P1 fractions obtained from P.capitatus present significant anticoagulant activity through the two aforementioned coagulation pathways, displayed in figure 3 and 4, studies have been performed to determine the monosaccharide composition regarding the com- pound of fraction PCA F44 P1, with a 30-fold higher activity compared to PCA F23 P1.

The PCA F44 P1 structure was analyzed by GC-MS and $100 \%$ of galactose (Figure 7) was detected. These results might again contrast with the literature, since according to RAY (2006), SP extracted from green algae generally display monosaccharide heterogeneity. Although, the most common source of

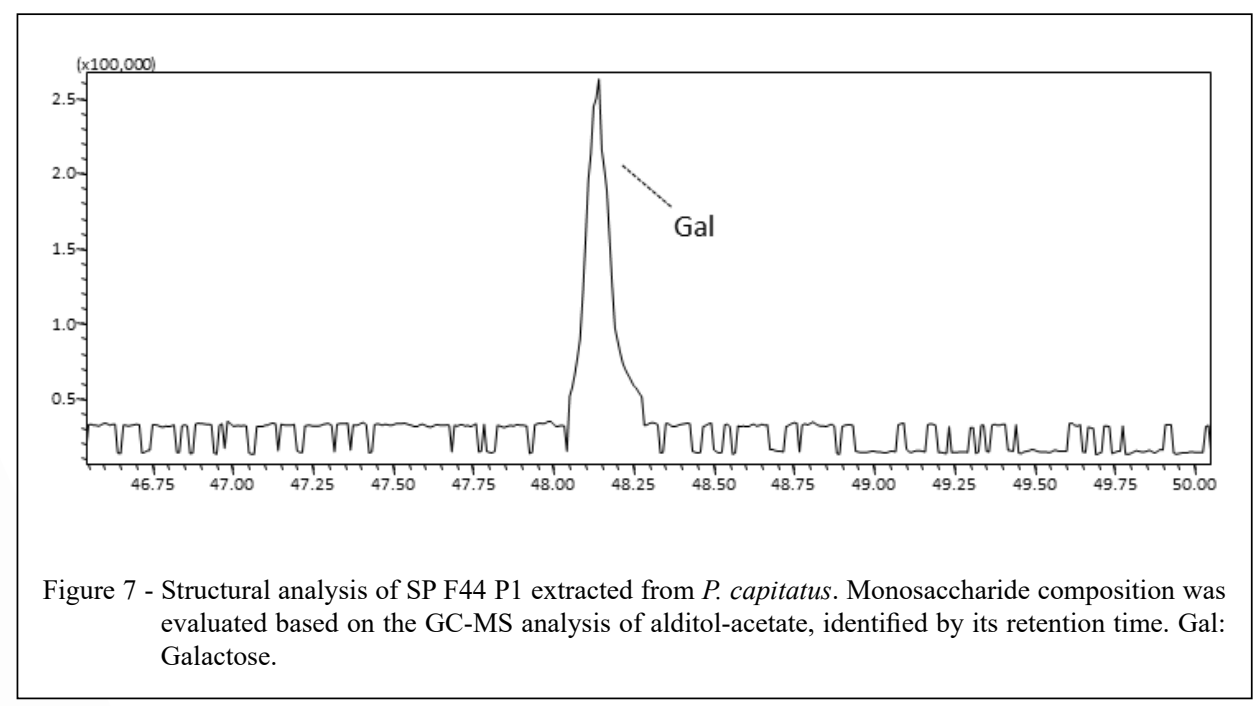

Ciência Rural, v.51, n.8, 2021. 
sulfated galactans is red seaweeds, some green algae are also significant sources of these molecules. The sulfated galactans expressed in green algae are usually more complex and heterogeneous when compared to red algae (FARIAS et al., 2008).

\section{CONCLUSION}

Five SP fractions extracted from the green algae $P$. capitatus precipitated in increasing ethanol concentrations; and subsequently, purified by anion exchange chromatography were obtained in the present study. Fractions F23 P1 and F44 P1 displayed higher activity compared to the other fractions in an in vitro aPTT assay, prolonging plasma clotting time at approximately 6 and $2 \mathrm{IU} / \mathrm{ml}$, respectively. The same activity was observed in the PT test, prolonging time at about $16 \mathrm{IU} / \mathrm{mL}$. In a trial in the presence of proteases belonging to the coagulation cascade, the mechanism of action of both fractions took place preferably via factor Xa mediated by antithrombin. As the fraction PCA F44 P1 exhibited higher anticoagulant potential, it was partially characterized by GC-MS as a sulphated galactan ; although, further structural studies must be performed in order to fully elucidate its chemical structure and better understand its mechanism of action.

\section{ACKNOWLEDGMENTS}

This work was supported by grants from Fundação de Amparo à Pesquisa do Estado do Rio de Janeiro (FAPERJ), Conselho Nacional de Desenvolvimento Científico e Tecnológico (CNPq), Coordenação de Aperfeiçoamento de Pessoal de Nível Superior (CAPES) and Empresa de Pesquisa Agropecuária do Estado do Rio de Janeiro (PESAGRO-RIO).

\section{DECLARATION OF CONFLICT OF INTERESTS}

The authors declare no potential conflicts of interest with respect to the research, authorship, and/or publication of this article.

\section{REFERENCES}

ALE, M. T. et al., Important determinants for fucoidan bioactivity: A critical review of structure-function relations and extraction methods for fucose-containing sulfated polysaccharides from brow seaweeds. Marine Drugs, v.9, n.10, p.2106-2130, 2011. Available from: <https://doi.org/10.3390/md9102106>. Accessed: Jan. 18, 2020. doi: $10.3390 / \mathrm{md} 9102106$.

ANDERSON, L. O. et al. Anticoagulant properties of heparin fractionated by affinity chromatography on matrix-bound antithrombin-3 and by gel-filtration. Thromb Res, v.9, p.575-580, 1976. Available from: $<$ https://pubmed.ncbi.nlm.nih.gov/1006626/>. Accessed: Jan. 30, 2020. doi: 10.1016/0049-3848(76)90105-5.
ARATA, P. X., et al. Chemical structure and anticoagulant activity of highly pyruvylated sulfated galactans from tropical green seaweeds of the order Bryopsidales. Carbohydrate Polymers, v.122, p.376-386, 2015. Available from: <https://pubmed.ncbi. nlm.nih.gov/25817682/>. Accessed: Feb. 20, 2020. doi: 10.1016/j. carbpol.2014.10.030.

ATHUKORALA, Y. et al. An anticoagulative polysaccharide from an enzymatic hydrolysate of Ecklonia cava. Carbohydrate Polymers, v.66, n.2, p.184-191, 2006. Available from: $<$ https://www.sciencedirect.com/science/article/abs/pii/ S0144861706001196?via\%3Dihub>. Accessed: Jan. 18, 2020. doi: 10.1016/J.CARBPOL.2006.03.002.

BERLINCK R. G. S. et al. Challenges and rewards of research in marine natural products chemistry in Brazil. J Nat Prod. v.67, p.510-522, 2004. Available from: <https://pubs.acs.org/ doi/10.1021/np0304316>. Accessed: Feb. 20, 2020. doi: 10.1021/ np0304316.

BEZERRA-NETO, J. T. B. et al. Sulfated polysacchardes of the alga Caulerpa sertularioides (GMEL.) howe: analysis of methods of precipitation. Revista Brasileira de Engenharia de Pesca, v.3, n.2, p.50-62, 2008. Available from: <https://doi.org/10.18817/ repesca.v3i2.72>. Accessed: Dec. 15, 2019. doi: 10.18817/repesca. v3i2.72.

BILAN, M. I. et al. Structure of a highly pyruvylated galactan sulfate from the pacific green alga Codium yezoense (Bryopsidales, Chlorophyta). Carbohydrate Research, 342, 586-596, 2007. Available from: <https://pubmed.ncbi.nlm.nih.gov/17134684/>. Accessed: Nov. 20, 2019. doi: 10.1016/j.carres.2006.11.008.

BLOSSOM, D. B. et al. Outbreak of adverse reactions associated with contaminated heparin. N Engl J Med; 359:2674-84, 2008. Available from: <https://www.researchgate.net/ publication/23567068 Outbreak of Adverse Reactions Associated_with_Contaminated_Heparin $>$. Accessed: May, 10, 2020. doi: 10.1056 /NEJMoa 0806450 .

BONEY, A. D. A biology of marine algae, Hutchinson Ltd., New York, p.216, 1966.

BRADFORD, M. M. A. Rapid and sensitive method for the quantification of microgram quantities of protein utilizing the principle of protein-dye binding. Analytical Biochemistry, v.72, n.1-2, p.248-254, 1976. Available from: <https://doi. org/10.1016/0003-2697(76)90527-3https://doi.org/10.1016/00032697(76)90527-3>. Accessed: Jan. 30, 2020. doi: 10.1016/00032697(76)90527-3.

BRANDÃO, T. B. P. et al. Insights on chemical-biological correlations learned from investigations on the sulfated galactan from the marine alga Bothryocladia occidentalis. International Journal of Biological Macromolecules, v.158, p.471-476, 2020. Available from: <https://doi.org/10.1016/j.ijbiomac.2020.04.085>. Accessed: Sep. 25, 2020. doi: 10.1016/j.ijbiomac.2020.04.085.

CHATTOPADHYAY, K. et al. Polysaccharides from Caulerpa racemosa: purification and structural features. Carbohydrate Polymers, 68, 407-415, 2007. Available from: <https://doi. org/10.1016/j.carbpol.2006.12.010>. Accessed: Jun. 20, 2020. doi: 10.1016/j.carbpol.2006.12.010.

CHEVOLOT, L. et al. Further data on the structure of brown seaweed fucans: relationships with anticoagulant activity. 
Carbohydr Res, 319: 154-165, 1999. Available from: <https:// pubmed.ncbi.nlm.nih.gov/10520264/>. Accessed: Jul. 10, 2020. doi: 10.1016/s0008-6215(99)00127-5.

CIANCIA, M. et al. Characterization of cell wall polysaccharides of the coencocytic green seaweed Bryopsis plumosa (Bryopsidaceae, Chlorophyta) from the Argentinecoast. Journal of Phycology, 48, 326-335, 2012. Available from: < https://pubmed.ncbi.nlm.nih. gov/27009722/>. Accessed: Jun. 13, 2020. doi: 10.1111/j.15298817.2012.01131.x.

CINELLI, L. P. et al. Seminal fluid from sea urchin (Lytechinus variegatus) contains complex sulfated polysaccharides linked to protein. Comp Biochem Physiol B Biochem Mol Biol, Sep., 154, 1, 108-112, 2009. Available from: <https://doi.org/10.1016/j cbpb.2009.05.004>. Accessed: Jun. 20, 2020. doi: 10.1016/j. cbpb.2009.05.004.

CUMASHI, A. et al. Consorzio Interuniversitario Nazionale per la Bio-Oncologia, Italy. A comparative study of the anti-inflammatory, anticoagulant, antiangiogenic, and antiadhesive activities of nine different fucoidans from brown seaweeds. Glycobiology, 17, 541-552, 2007. Available from: $<$ https://pubmed.ncbi.nlm.nih.gov/17296677/>. Accessed: Aug. 8, 2020. doi: 10.1093/glycob/cwm014.

DENG, Q. et al. Structural characterization, modification and hepatoprotective effects of polysaccharide from Mori Fructus. International Journal of Biological Macromolecules, v.153, p.357-363, 2020. Available from: <https://doi.org/10.1016/j. ijbiomac.2020.02.300>. Accessed: Sep. 12, 2020. doi: 10.1016/j. ijbiomac.2020.02.300.

DIETRICH, C. P. et al. Electrophoretic behaviour of acidic mucopolysaccharides in diamine buffers. Analytical Biochemistry, v.70, n.02, p.645-647, 1976. Available from: $<$ https://doi.org/10.1016/0003-2697(76)90496-6>. Accessed: May, 20, 2020. doi: 10.1016/0003-2697(76)90496-6.

DODGSON, K. S. et al. A note on the determination of the ester sulphate content of sulphated polysaccharides. Biochemical Journal, v.84, p.106-110, 1962. Available from: <https://pubmed. ncbi.nlm.nih.gov/13886865/>. Accessed: Jun. 28, 2020. doi: 10.1042/bj0840106.

DUBOIS, M. et al. Colorimetric method for determination of sugars and related substances. Analytical Chemistry, v.28, n.03, p.350-356, 1956. Available from: <https://doi.org/10.1021/ ac60111a017>. Accessed: Jul. 10, 2020. doi: 10.1021/ac60111a017.

ESTEVEZ, J. M. et al. Chemical and in situ characterization macromolecular components of cell walls from the green seaweed Codium fragile. Glycobiology, v.19, p.212-228, 2009. Available from: <https://pubmed.ncbi.nlm.nih.gov/18832454/>. Accessed: Jul. 12, 2020. doi: 10.1093/glycob/cwn101.

FARIAS, W. R. L. et al. Structure and anticoagulant activity of sulfated galactans - Isolation of a unique sulfated galactan from the red algae Botryocladia occidentalis and comparison of its anticoagulant action with that of sulfated galactans from invertebrates. J Biol Chem; 275:29299-307, 2000. Available from: <https://pubmed.ncbi.nlm.nih.gov/10882718/>. Accessed: Mar. 7, 2020. doi: 10.1074/jbc.M002422200.

FARIAS, W. R. L. et al. Dual effects of sulfated D-galactans from the red algae Botryocladia occidentalis preventing thrombosis and inducing platelet aggregation. Thromb Haemostasis;
86:1540-1546, 2001. Available from: <https://pubmed.ncbi.nlm. nih.gov/11776325/>. Accessed: Feb. 20, 2020. doi: 10.1055/S-00371616760 .

FARIAS, E. H. et al. A preponderantly 4-sulfated, 3-linked galactan from the green alga Codium isthmocladum. Glycobiology. v.18, n.3, p.250-259, 2008. Available from: <https://pubmed.ncbi.nlm. nih.gov/18174311/>. Accessed: Feb. 19, 2020. Epub 3-Jan-2008. doi:10.1093/glycob/cwm139.

FONSECA, R. J. C. et al. Slight differences in sulfatation of algal galactans account for differences in their anticoagulant and venous antithrombotic activities. Thrombosis and Haemostasis, v.99, n.3, p.539-545, 2008. Available from: $<$ https://pubmed.ncbi.nlm.nih.gov/18327402/>. Accessed: Jun. 20, 2020. doi: 10.1160/TH07-10-0603.

HAROUN-BOUHEDJA, F. et al. Relation between sulfato groups and biological activities of fucans. Thromb. Res. 100, 453-459, 2000. Available from: <https://pubmed.ncbi.nlm.nih. gov/11150589/>. Accessed: Aug. 05, 2020. doi: 10.1016/s00493848(00)00338-8.

KELTON, J. G. et al. Bleeding associated with antithrombotic therapy. Seminars Hematology, 17, 259-291, 1980. Available from: <https://pubmed.ncbi.nlm.nih.gov/6160618/>. Accessed: Jan. 12, 2020. PMID: 6160618.

KIRCHER, H. W. Gas-liquid chromatography of methylated sugars. General Carbohydrate Method, 32, 1103-1106, 1972. Available from: $<$ https://doi.org/10.1016/B978-0-12-7462066.50012-6>. Accessed: Feb. 06, 2020. doi: 10.1016/B978-0-12746206-6.50012-6.

LEITE, E. L. et al. Struture of a new fucan from the algae Spatoglossum schroederi. Plant science. v.132, n., p.14, 1998. Available from: <https://doi.org/10.1590/S0100879X2001000500009>. Accessed: May, 20, 2020. doi: 10.1590/ S0100-879X2001000500009.

MATSUBARA, K. et al. Purification and characterization of a fibrinolytic enzyme and identification of fibrinogen clotting enzyme in a marine green alga, Codium divaricatum. Comp Biochem Physiol B Biochem Mol Biol, 125: 137-143, 2000. Available from: <https://pubmed.ncbi.nlm.nih.gov/10840649/>. Accessed: Feb. 12, 2020. doi: 10.1016/s0305-0491(99)00161-3.

MATSUBARA, K. et al. Anticoagulant properties of a sulfated galactan preparation from a marine green alga, Codium cylindricum. International Journal of Biological Macromolecules, v.28, n.5, p.395-399, 2001. Available from: <https://pubmed.ncbi.nlm.nih. gov/11325427/>. Accessed: Mar. 27, 2020. doi: 10.1016/s01418130(01)00137-4.

MOURÃO, P. A. Use of sulfated fucans as anticoagulant and antithromboticagents: Future perspectives. Current Pharmaceutical Design, 10, 967-981, 2004. Available from: $<$ https://pubmed.ncbi.nlm.nih.gov/15078127/>. Accessed: Apr. 10, 2020. doi: $10.2174 / 1381612043452730$.

PEREIRA, M. S. et al. Structure and anticoagulant activity of sulfated fucans -Comparison between the regular, repetitive, and linear fucans from echinoderms with the more heterogeneous and branched polymers from brown algae. J Biol Chem; 274:7656-7667, 1999. Available from: $<$ https://pubmed.ncbi.nlm.nih.gov/10075653/>. Accessed: Mar. 22, 2020. doi: 10.1074/jbc.274.12.7656. 
PEREIRA, M. S. et al. Is there a correlation between structure and anticoagulant action of sulfated galactans and sulfated fucans? Glycobiology; 12:573-80, 2002. Available from: <https://doi. org/10.1093/glycob/cwf077>. Accessed: Jan. 20, 2020. doi: 10.1093/glycob/cwf077.

PEREIRA, M. S. et al. A 2-sulfated, 3-linked alpha-L-galactan is an anticoagulant polysaccharide. Carbohydr Res; 337:22312238, 2002. Available from: <https://doi.org/10.1016/S00086215(02)00215-X>. Accessed: Feb. 08, 2020. doi: 10.1016/S00086215(02)00215-X.

PEREIRA, M. G. et al. Structure and anticoagulant activity of a sulfated galactan from the red alga, Gelidium crinale. Is there a specific structural requirement for the anticoagulant action? Carbohydr Res, 340: 2015-2023, 2005. Available from: <https:// pubmed.ncbi.nlm.nih.gov/16023626/>. Accessed: Feb. 20, 2020 doi: 10.1016/j.carres.2005.05.018.

POMIN, V. H. et al. Specific sulfation and glycosylation-a structural combination for the anticoagulation of marine carbohydrates. Front Cell Infect Microbiol. Mar, 6, 4-33, 2014. Available from: $<$ https://pubmed.ncbi.nlm.nih.gov/24639954/>. Accessed: Jan. 24, 2020. doi: 10.3389/fcimb.2014.00033.

RAY, B. Polysaccharides from Enteromorpha compressa: Isolation, purification and structuralfeatures. Carbohydr. Polym. 66, 408-416, 2006. Available from: <https://doi.org/10.1016/j. carbpol.2006.03.027>. Accessed: Jan. 20, 2020. doi: 10.1016/j. carbpol.2006.03.027

ROCHA, H. A. et al. Structural and hemostatic activities of a sulfated galactofucan from the brown alga Spatoglossum schröederi. An ideal antithrombotic agent. Journal of Biological Chemistry, v.280, p.41278-41288, 2005. Available from: <https:// pubmed.ncbi.nlm.nih.gov/16174777/>. Accessed: Jan. 09, 2020. Epub 20-Sep-2005. doi: 10.1074/jbc.M501124200.
SILVERSTEIN, R. M. et al. Identificação espectrométrica de compostos orgânicos. 7 ed. Rio de Janeiro: LTC, 2006.

TEIXEIRA, V. L. Produtos Naturais Marinhos. In: Pereira, R.C. \& Soares-Gomes, A. Biologia Marinha, Rio de Janeiro, p.443472, 2009.

THIERS, B. Index Herbariorum: A Global Directory of Public Herbaria and Associated Staff. New York Botanical Garden's Virtual Herbarium, 2016. Available from: $<$ http://sweetgum.nybg. org/science/ih/>. Accessed: Mar. 09, 2020.

UEHARA, T. et al. Studies on anticoagulant-active arabinan sulfates from the green alga, Codium latum. Carbohydr Res, 235:309-311, 1992. Available from: <https://pubmed.ncbi.nlm. nih.gov/1473111/>. Accessed: Jun. 10, 2020. doi: 10.1016/00086215(92)80100-f.

WARKENTIN, T. E. et al. Temporal aspects of heparin-induced thrombocytopenia. N Engl J Med.; 344:1286-1292, 2001. Available from: <https://www.nejm.org/doi/full/10.1056/ NEJM200104263441704 >. Accessed: Jan. 27, 2020. doi: 10.1056/ NEJM200104263441704.

WU, N. et al., Depolymerization of fucosylated chondroitin sulfate from sea cucumber, Pearsonothuria graeffei, via $60 \mathrm{Co}$ irradiation. Carbohydrate polymers, v.93, p.604-614, 2013. Available from: <https://pubmed.ncbi.nlm.nih.gov/23499102/>. Accessed: Feb. 20, 2020. Epub 26-Dec-2012. doi: 10.1016/j. carbpol.2012.12.044.

ZHANG, H. J. et al. Chemical characteristics and anticoagulant activities of a sulfated polysaccharide and its fragments from Monostroma latissimum. Carbohydrate Polymers, v.71, n.03, p.428-434, 2008. Available from: <https://doi.org/10.1016/j. carbpol.2007.06.012>. Accessed: Feb. 15, 2020. doi: 10.1016/j. carbpol.2007.06.012. 